\title{
Political Volunteerism: Electoral Process of Independent Candidates in Jogja Independent (JOINT)
}

\author{
Alhafiz Atsari \\ Faculty of Social and Political Science \\ Muhammadiyah Yogyakarta University \\ Bantul, Yogyakarta \\ alhafiz.atsari0@gmail.com \\ David Efendi \\ Faculty of Social and Political Science \\ Muhammadiyah Yogyakarta University \\ Bantul, Yogyakarta \\ defendi@umy.ac.id \\ Bambang Eka Cahya Widodo \\ Faculty of Social and Political Science \\ Muhammadiyah Yogyakarta University \\ Bantul, Yogyakarta \\ bec.widodo@gmail.com
}

\begin{abstract}
There is a new phenomenon organized by people in Yogyakarta city-affiliated with a volunteerism movement called Jogja Independent (JOINT). It endeavored to nominate and demonstrate how independent candidates battled in Yogyakarta city's election in 2017. It was conducted by electing several candidates in public. This research was conducted to apprehend the process of independent candidate's election conducted by JOINT. By doing observation, interview and theory analysis, this paper determined some conclusions that the process of independent candidate's election conducted by JOINT had been a bandwagon and democratic. The election processes were divided into four steps: candidate nomination, appointing selectors, public fit, and proper test, and deciding the final candidate. It resulted in a couple of candidates elected democratically.

Keywords-Candidate Election; Independent
\end{abstract} Candidates; Jogja Independent; Electoral

\section{INTRODUCTION}

The democratic transition in general other than marked by the collapse of the authoritarian regime is a strong hope of high optimism towards the immediate achievement of the end of the struggle by formed of civil society in the national to local political arena [4]. The term civil society which used by Alexis de 'Tocqueville is defined as organized and characterized social life areas such as voluntary, selfgenerating, self-supporting, high self-reliance with the state, and obedient with the norms or legal values followed by its citizens. The election in Indonesia is demonstrated by the emergence of the phenomenon of political volunteerism lately. The emergence of volunteers cannot be separated from the culture of Indonesian society who enthusiastic to work together [20]. The birth of the voluntarism movement is a manifestation of community participation in the democratic system and cites the term Sorensen as a mass-dominated democracy as a system with mass actors who have power over traditional ruling classes. They encouraged reforms from below, attacked the power and privileges of the elite [21].

Jogja Independent (JOINT) is a movement initiated by the people of Yogyakarta City in March 2016 to escort and battle the general election of the head of the region to be held in early 2017. The birth of JOINT is inseparable from the concern of some people of Yogyakarta City against the poor process of recruitment of political parties in Indonesia and the leadership of Haryadi Suyuti as a mayor for five years in Yogyakarta City. Recruitment processes which have been happening are the prevalence of nepotism behavior which occurs in the body of political parties by distributing power to certain families or people without open process. People who do not have capital will not be able to follow the process of candidacy by political parties. Political parties tend to provide an easy way for candidates originating from their group such as the candidate originates from the party leadership as well as party officials who have strong influence. It does not conduct well with the candidate election process of political party that produces the leader of what Firmanzah calls the peanut-fry politics, i.e., instant politics and without debriefing as long as the candidate has high popularity in society [8].

JOINT provides an alternative nomination process for candidates for regional heads through an independent channel by eliminating the practice of money politics in political parties. This alternative becomes a new phenomenon because of the formation of a new movement and the process of political education which in a narrow coverage addressed to the people of Yogyakarta City and in wide coverage to the people of Indonesia. It explains what Mansour Fakih means as a power which is the core of social structure and leads to the struggle to get it [6]. 


\section{CANDIDACY OF JOINT: NON-POLITICAL PARTY MOVEMENT}

There are four democracy steps in JOINT: candidate nomination, appointing selectors, public fit and proper test, and deciding the final candidate.

\section{A. Candidate Nomination}

All citizens have a great chance to register as a candidate to be carried by JOINT. It illustrates the inclusiveness of JOINT in nominating who is eligible to register as candidates and additional terms for political education to avoid nepotism and other atrocious practices related to the process of candidacy by political parties. The diversity of leaders or communities enrolling in JOINT demonstrates the well-established presence of candidates' autonomous spaces in fragmented social and political environments. The impact of this presence exhibits the process of democratization which is a process of social transformation of cultural, social, economic, and political aspects as well as other aspects of life [6].

Shortly after the declaration, JOINT published the candidate criteria including personal capacity (capability, competence, responsibility, and integrity) and various administrative requirements from the General Election Commission. JOINT also requires every participant to register with his small team as proof that the candidate has the support of his circles, colleagues, and also his relatives. Moreover, JOINT attracts candidates who are not only popular but have a sense of alignment with the community. Based on the political literature, the quality of the characters includes several dimensions: competence, integrity, firmness, empathy, and joy [17].

Candidates enrolling in JOINT originate from diverse professional backgrounds and competencies such as academics, practitioners, artists, and non-governmental organizations. The following table is a list of names of potential JOINT' mayor candidates:

\section{TABLE 1. PROSPECTIVE CANDIDATE LISF OF JOINT} MAYOR

\begin{tabular}{|l|l|l|}
\hline No & Name & Occupation \\
\hline 1 & Andrie Primera Nuary & Employee of private bank \\
\hline 2 & Akhyari Hananta & $\begin{array}{l}\text { Non-government } \\
\text { organization }\end{array}$ \\
\hline 3 & Arbhak Yoga Widodo & Civil servant \\
\hline 4 & Dani Eko Wiyono & Artist \\
\hline 5 & Emmy Yuniarti Rusadi & Researcher \\
\hline 6 & Esha Satya Syamjaya & Entrepreneur \\
\hline 7 & Fitri Paulina Andriani & Civil servant \\
\hline 8 & Garin Nugroho Riyanto & Director \\
\hline 9 & Martha Haenry A & Businessman \\
\hline 10 & Hambar Riyadi & $\begin{array}{l}\text { Director of Anak Wayang } \\
\text { Indonesia Community }\end{array}$ \\
\hline 11 & Rommy Heryanto & Consultant \\
\hline 12 & $\begin{array}{l}\text { Siti Ruhaini } \\
\text { Dzuhayatin }\end{array}$ & Lecturer \\
\hline 13 & Titok Hariyanto & Researcher \\
\hline
\end{tabular}

\begin{tabular}{|l|l|l|}
\hline 14 & Transtoto Handadhari & Retired Civil Servant \\
\hline 15 & Lusy Laksita & $\begin{array}{l}\text { Master of Ceremony, } \\
\text { broadcaster, and trainer }\end{array}$ \\
\hline
\end{tabular}

\section{B. Appointing Selectors}

Based on the Rahat and Hazan theory in Katz and Crotty used by the author, the selection model of JOINT selection is considered as exclusive. JOINT formed a convention committee team consisting of five people from various professional backgrounds such as Busyro Muqoddas as a legal practitioner, Bambang Eka Cahya Widodo as academic or election expert, Herry Zudianto as the former mayor of Yogyakarta, Yustina Neni as an artist, and Suparman Marzuki as a legal practitioner [19]. This team is called a team of five. Team five is assigned to select the names of those who are eligible to be selected as selectors. The team hunts anyone who desires to be selectors of JOINT. However, not every member of JOINT has a role to determine the eligibility of the selectors.

The result was a panel of conventions consisting of nine people from various elements of society with expertise on different issues: leadership ethics, law enforcement, anticorruption, spatial and environmental, women and public health, public finance, bureaucracy improvement), business and tourism, macro economy, culture, art, international relations and urban politics. These nine selectors are called as the team of nine.

The nine selectors were set because of the critical awareness of the convention committee team. They can be referred as the critical citizen [17]. Education is crucial for democracy because education is believed to be a social institution where learners are widely socialized with the values of freedom and equality which are the basic components of democracy ([17].

It describes a phenomenon of social movement that is different from the one developed by Escobar and Alvarez as a movement that does not merely place itself in the public arena - does not limit itself to traditional political activities and rejects a deeply embedded way of understanding political practices and its relationship to culture, economy, and society [5]. In fact, there is a panelist team selected only because of the proximity without considering the willingness of the selector. It can be concluded that the convention committee team is also not democratic in determining the eligibility of the selectors. One of selector said that "...he selected nothing".

The limited role of these raises a dilemma because time factor also became one of the breeds of the closed role of students in determining the selectors. JOINT only provides fourteen days to all citizens to register as a potential JOINT participant since JOINT was declared March 20, 2016.

The limited time that the volunteers have as many academic activities leaves them excluded in determining the selector. Moreover, the active volunteers are fifteen persons from seventy-two. With the limited number of volunteers and 
a large number of JOINT activities at that time, students should be given different tasks which aid in keeping the secretariat, assisting the administration of candidates such as selection of candidate files, and assisting JOINT activity process. Not only to play a role in the administration process, but students also play a role in distributing voting cards to the present people to vote to nominate candidates in the convention process and collect identity cards of around 45,000. Regretfully, citizens' involvement in determining JOINT selector is not available.

\section{Public Fit and Proper Test}

Based on the theory of Rahat and Hazan, JOINT uses and combines exclusive candidate selection method and functional decentralization [19]. In this case, JOINT does not have a structure like a political party. JOINT does not have a leadership at the national level. JOINT is a local community that only covers the city of Yogyakarta. Therefore, no screening process is organized at the national level in the same way that political party processes organize.

JOINT creates a basic element of criteria or skill mastery which has to be comprehended by nine selectors like functional decentralization conducted in the process of candidate political party by ensuring representation for representatives such as unions, women, etc.

The representative groups are a team of nine. They are divided into two teams which are placed on two sessions of the candidate process; Pre-convention and convention. JOINT has set up a series of agenda in April 2016. Starting on April 3 , 2016, the agenda of candidate introduction which was attended by 13 candidates, this event was named Sarasehan Sinau Bareng Demokrasi ala Jogja.

After JOINT introduces candidates on April 3, 2016, JOINT also conducts its first step of public test for one week from April 3 to April 9, 2016. JOINT offers the opportunity to the citizen to convey in writing about the personal fifteen candidates with evidence about deviant behaviors that candidates have ever done, laws of contradictory behavior, and social norms.

At the time of the pre-convention on April, 10 ${ }^{\text {th }} 2016$, this pre-convention is closed for public. Furthermore, it does not involve the citizens, students, and initiators who are members of JOINT. Selection is only from the team of nine. At this step, fifteen candidates are given an opportunity to prepare the material to be presented. They convey the deepening of vision and mission as well as the leading work program.

The selectors exploit quantitative assessments based on key performance indicators prepared by panelists who focus on technical capabilities and mastery of what is the foundation or platform of JOINT. Moreover, It is not well documented by JOINT. Thus, the data on the assessment are not able to be described properly.

The result of the pre-convention process is the establishment of five candidates who will proceed to the next stage or convention on April 13, 2016. Candidates who pass the pre-convention stage will be publicly tested in the second step for three days from April 13 to April 15, 2016. The second step public test method is also the same as the first step of the public test.

The last step is the convention step. It was held on April 17, 2016, at Jogja Expo Center. It is the final step in which five candidates will be tested for eligibility by the selector team as well as the people present.

The participation or involvement of the community in determining the eligible candidates should be brought forward when JOINT had entered the convention step to select several of the candidates to be mayor and vice mayor. Elements of the present citizen consist of a public figure, members of communities and members of political parties who have voting rights in the Yogyakarta City elections.

Both at the time of the pre-convention and convention, volunteers who in this case the group of students does not gain the authority to give arguments to the candidates who are contesting. There are several factors which cause it to happen. Not all students who are members of JOINT are residents who have identity cards of Yogyakarta. However, JOINT also is not able to be sure that all participants who attend the convention and argue and test the ability of candidates are citizens who have ID card of Yogyakarta. JOINT does not record and document well how many students who originate from inside and outside of Yogyakarta.

\section{Deciding final Candidate}

JOINT applies two models in assigning candidates such as designation model and selection model. Both models are used because JOINT has two convention steps.

Firstly, the pre-convention. JOINT only conducts trials by the selector team with no people involvement. Five candidates resulting from the pre-convention are candidates determined by appointment by the selector team. It is following the theory described by Rahat and Hazan on selection using a system of appointment is a process of non-democratic choice [19]. The absence of a hierarchy within the JOINT causes the selector team as political party agency deciding on a candidate.

Secondly, convention. JOINT employs an election model in the candidate determination. According to Rahat and Hazan, the election model on candidate determination is the process of selecting all candidates through election voting procedure without a selector which can change the list of compositions [19].

It is done in the convention process undertaken by JOINT. JOINT conducted voting from the 105 votes. Of 105 ballot papers, one ballot was declared invalid. The proportion of voters are divided into two parts: from the chairman of the villages and mass organization and people. The votes originating from the chairman of the villages and mass organizations have a higher value one level than people.

Candidates who finally established as a candidate for mayor and vice mayor who carried by JOINT are Garin Nugroho and Rommy Heryanto. They are not documented about the percentage of assessment weights among the selector teams, chairman of the villages, mass organizations and the citizens.

The results of the determination by JOINT reflect a democratic process. Meaning, that all citizens are invited to 
determine who will be the mayor promoted by JOINT by involving at the convention process. Therefore, JOINT exhibits that the voice of the people is significant not only in determining who is in power but also whether the process of electing and mandating the JOINT are democratic, honest and fair or in the opposite. Like what Gramsci said, JOINT, in a certain way, is a movement where people create alteration and history so, citizen appraisals, in this case, are a democratic legitimacy of JOINT [11].

On the other hand, JOINT failed to collect 45,000 ID cards which is a requirement set by the KPU. Moreover, JOINT gains obstacles in fulfilling the verification requirements by the KPU. There is factual verification by census method by directly meeting each supporting candidate who submitted his / her ID card. If the supporters of the candidate cannot be found, the candidates will be given the opportunity to present them at KPU. However, if the candidates cannot bring their supporters to KPU, the candidate's support will not be eligible. It means that there is an odd task to be performed by JOINT concerning the verification of the KTP supporters.

\section{CONCLUSION}

Some important findings, firstly, the political process at the local level is not always the domain of a political party. The case of Jogja demonstrates the dynamics of non-party political movements that are organized in JOINT practicing procedural democracy and scheduling changes in political power amidst a firm electoral regime. Second, the movement of political volunteerism in Jogja as a movement for the education of democracy is adequate. Nevertheless, as a real political movement there are still various obstacles which will make this movement fade before developing.

\section{REFERENCES}

[1] Barghoon, F. C, "Soviet Political Culture," In G. A. Verba, "Budaya Politik: Tingkah Laku Politik dan Demokrasi di Lima Negara” (edisi kedua) (p. 3). Jakarta: Bumi Aksara, 1990.

[2] Budiman, A, "Peranan Mahasiswa sebagai Intelegensia". In A. Mahasin, \& I. Natsir, "Cendikiawan dan Politik (Cetakan II') (pp. 150-151). Jakarta: LP3ES, 1984.

[3] Coleman, J, "Social Capital in The Creation of Human Capital," In F. Fukuyama, "Trust: Kebajikan Sosial dan Penciptaan Kemakmuran (Cetakan kedua)," (p. 12). Yogyakarta: PENERBIT QALAM, 2010.

[4] Deni, A, “Konsolidasi Demokrasi: Menuju Keberlanjutan Politik Indonesia Pasca Soeharto," Ternate: Ummu Press, 2006.

[5] Escobar, A., \& Alvarez, S. E, "The Making of Social Movements in Latin America". In M. Fakih, "Masyarakat
Sipil untuk Transformasi Sosial: Pergolakan Ideologi LSM Indonesia" (p. 43). Yogyakarta: INSISTPress, 2010.

[6] Fakih, M. "Masyarakat Sipil untuk Transformasi Sosial: Pergolakan Ideologi LSM di Indonesia". Yogyakarta: INSISTPress, 2010.

[7] Fashri, F, "Penyingkapan Kuasa Simbol: Apropriasi Reflektif Pemikiran Pierre Bourdieu". Yogyakarta: JUXTAPOSE THE SUMRADEWI OFFICE HOUSE, 2007.

[8] Firmanzah, "Mengelola Partai Politik: Komunikasi dan Positioning Ideologi Politik di Era Demokrasi," Jakarta: Yayasan Pustaka Obor Indonesia, 2011.

[9] Fukuyama, F, “Trust: Kebajikan Sosial dan Penciptaan Kemakmuran (Cetakan Kedua)," Yogyakarta: PENERBIT QALAM, 2010.

[10] Gore, M. S, "The Concept of Social Movement". In R. Singh, "Gerakan Sosial Baru," (p. 184). Yogyakarta: Resist Book, 2010.

[11] Gramsci, A, "Prison Notebooks". In M. Fakih, "Masyarakat Sipil untuk Transformasi Sosial: Pergolakan Ideologi LSM Indonesia" (p. 56). Yogyakarta: INSISTPress, 2010.

[12] Kompas, "Jogja Independent” Usung Pasangan GarinRommy”. Jakarta: Harian Kompas, 2016.

[13] Kompas, "Gerakan Kerelawanan dalam Sejarah". jakarta: kompas, 2016.

[14] Kompas, “Mengatasi Pilkada Minus Kontestan”. Jakarta: Harian Kompas, 2016.

[15] Kompas, "Pilkada DKI Jakarta: Kemanakah Basuki Akan Berlabuh?" Jakarta: Kompas, 2016.

[16] Latif, Y "Genealogi Intelegensia: Pengetahuan dan Kekuasaan Intelegensia Muslim Indonesia Abad XX”. Jakarta: KENCANA, 2013.

[17] Mujani, S., Liddle, R. W., \& Ambardi, K, “Kuasa Rakyat: Analisis tentang Perilaku Memilih dalam Pemilihan Legislatif dan Presiden Indonesia Pasca-Orde Baru", Jakarta: Mizan Publika, 2011.

[18] Porta, D. D., \& Diani, M, "Social Movements: An Introduction". In Y. Latif, "Genealogi Intelegensia: Pengetahuan dan Kekuasaan Intelegensia Muslim Abad $X X^{\prime}$, (p. 142). Jakarta: KENCANA, 2013.

[19] Rahat, G., \& Hazan, R. Y, "Seleksi Calon: Metode dan Seleksi". In R. Katz, \& W. Crotty, "Handbook Partai Politik" (pp. 182-183). Bandung: Penerbit Nusa Media, 2013.

[20] Samah, K., \& Susanti, F. R, "Berpolitik Tanpa Partai: Fenomena Relawan dalam Pilpres", Jakarta: PT Gramedia Pustaka Utama, 2015.

[21] Sorensen, G, "Demokrasi dan Demokratisasi: Proses dan Prospek dalam Sebuah Dunia yang Sedang Berubah". Yogyakarta: Pustaka Pelajar, 2003.

[22] Verba, G. A, "Budaya Politik: Tingkah Laku Politik dan Demokrasi di Lima Negara (edisi kedua)", Jakarta: Bumi Aksara,

1990. 